\title{
Alpine vascular plant species richness: the importance of daily maximum temperature and $\mathrm{pH}$
}

\author{
C.M. Vonlanthen ${ }^{1, *}$, P.M. Kammer ${ }^{2}$, W. Eugster ${ }^{3}$, A. Bühler ${ }^{1}$ and H. Veit ${ }^{1}$ \\ ${ }^{1}$ Institute of Geography, University of Berne, Hallerstrasse 12, 3012 Berne, Switzerland; ${ }^{2}$ LLB S1 Biology, \\ Canton and University of Berne, Gertrud-Wokerstrasse 5, 3012 Berne, Switzerland; ${ }^{3}$ Institute of Plant \\ Sciences, ETH Zentrum LFW C55.2, 8092 Zürich, Switzerland; *Author for correspondence (e-mail: \\ corinne.vonlanthen@giub.unibe.ch)
}

Received 3 March 2005; accepted in revised form 16 October 2005

Key words: Alpine vegetation, Intermediate disturbance hypothesis, Intermediate stress hypothesis, Microclimate, Soil nutrients, Standing crop

\begin{abstract}
Species richness in the alpine zone varies dramatically when communities are compared. We explored (i) which stress and disturbance factors were highly correlated with species richness, (ii) whether the intermediate stress hypothesis (ISH) and the intermediate disturbance hypothesis (IDH) can be applied to alpine ecosystems, and (iii) whether standing crop can be used as an easily measurable surrogate for causal factors determining species richness in the alpine zone. Species numbers and standing crop were determined in 14 alpine plant communities in the Swiss Alps. To quantify the stress and disturbance factors in each community, air temperature, relative air humidity, wind speed, global radiation, UV-B radiation, length of the growing season, soil suction, $\mathrm{pH}$, main soil nutrients, waterlogging, soil movement, number of avalanches, level of denudation, winter dieback, herbivory, wind damage, and days with frost were measured or observed. The present study revealed that $82 \%$ of the variance in vascular species richness among sites could be explained by just two abiotic factors, daily maximum temperature and soil $\mathrm{pH}$. Daily maximum temperature and $\mathrm{pH}$ affect species richness both directly and via their effects on other environmental variables. Some stress and disturbance factors were related to species richness in a monotonic way, others in an unimodal way. Monotonic relationships suggest that the harsher the environment is, the fewer species can survive in such habitats. In cases of unimodal relationships (ISH and IDH) species richness decreases at both ends of the gradients due to the harsh environment and/or the interaction of other environmental factors. Competition and disturbance seemed only to play a secondary role in the form of fine-tuning species richness in specific communities. Thus, we concluded that neither the ISH nor the IDH can be considered useful conceptual models for the alpine zone. Furthermore, we found that standing crop can be used as an easily measurable surrogate for causal factors determining species richness in the alpine zone, even though there is no direct causality.
\end{abstract}

\section{Introduction}

The vegetation near and above the timberline forms a small-scale mosaic of structurally and floristically different plant communities (e.g. Ellenberg 1996). Species richness varies considerably among these communities (e.g. Onipchenko and Semenova 1995; Kammer and Möhl 2002). These 
important differences in species richness in the alpine life zone are not yet fully understood, and few studies have focused on this topic (Onipchenko and Semenova 1995). In nonalpine ecosystems a wealth of diversity theories has been proposed during recent decades (e.g. Palmer 1994; Grace 1999) exploring the relationship between species richness and biomass, stress, and disturbance factors. Often discussed theories include the intermediate stress hypothesis (ISH) and the intermediate disturbance hypothesis (IDH).

The ISH predicts maximum species richness at moderate or intermediate ranges of environmental stress (Grime 1973, 1979). This is often interpreted as meaning that at high levels of stress the site is too harsh for many species to survive, whereas at low levels of stress the site is favourable and one or a few species dominate through competitive exclusion (Rosenzweig and Abramsky 1993). In this protocol stress is defined as an external constraint which limits biomass production of all or part of the vegetation (Grime 2001, p. 48).

The IDH predicts a unimodal relationship between species richness and disturbances: species richness should be maximal at intermediate intensities of disturbance, at intermediate frequencies of disturbance, and after an intermediate time span has elapsed after the last major disturbance (Grime 1973; Connell 1978; Sommer 1995). As a consequence, if disturbance occurs too frequently, species richness decreases because species that are intolerant to disturbance become locally extinct. If disturbances are too rare, richness decreases because dominant species use up a greater share of resources and thus eliminate weak competitors (Collins et al. 1995). In this study the definition of disturbance follows Grime (2001, p. 80): “...disturbance, which may be said to consist of the mechanisms which limit the plant biomass causing its partial or total destruction". In recent years, the IDH has often been tested, especially in aquatic systems (e.g. Fayolle et al. 1998; Flöder and Sommer 1999) and in grass- and shrublands where fire was the main disturbance factor (e.g. Beckage and Stout 2000; Engle et al. 2000).

Standing crop has often been used as a proxy for productivity and/or environmental factors determining species richness since it is relatively easy to measure (e.g. White et al. 1999). The relationship between standing crop and species richness depends on the spatial scale surveyed, and appears to be highly variable at any given scale (Waide et al. 1999; Mittelbach et al. 2001). At an intermediate spatial scale (within biomes but across communities), the standing crop-diversity relationship is most often unimodal with diversity peaking at intermediate values of standing crop (Waide et al. 1999; Mittelbach et al. 2001). Although data from different ecosystems have confirmed the expected pattern (Grace 1999), arctic data have demonstrated very little or no correlation between standing crop and species richness (e.g. Fox 1985; Waide et al. 1999; Gough et al. 2000). To the best of our knowledge, the relationship between species richness and standing crop among alpine plant communities has not been explored.

The aim of this study was to evaluate the importance of the major stress and disturbance factors potentially influencing the species richness of alpine plant communities. Although many ecological studies have been carried out in alpine plant communities (e.g. Müller et al. 2003), data making a quantitative comparison between richness and measured stress and disturbance factors possible are still not available. The following stress factors were measured or observed in 14 different plant communities: air temperature, relative air humidity, wind speed, global radiation, UV-B radiation, length of growing season, soil moisture, main soil nutrients, $\mathrm{pH}$, and water logging. In the same communities, the following disturbance factors were measured or observed: soil movement, denudation, avalanches, herbivory, wind damage, freezing damage, and winter dieback. Due to financial and logistical limitations, it was not possible to include more than 14 plant communities in our study, although, from a statistical point of view, this would have been desirable. These communities, however, cover the main vegetation types of the zone above treeline in the European Alps with the exception of rock surface and fen communities.

In this study, we first explored which stress and disturbance factors were highly correlated with species richness. Second, we examined whether the ISH and IDH can explain the observed patterns of species richness and environmental factors in alpine ecosystems. Third, we tested whether standing crop can be used as an easily measurable surrogate for causal factors in the alpine zone. 


\section{Research area}

Fourteen plant communities, including extreme communities such as scree slopes, wind-exposed communities, and snowbeds were chosen for investigation based on the close correspondence of their floristic composition (characteristic species, dominant species) and site factors (Table 1) with plant associations described in the phytosociological literature (e.g. Grabherr and Mucina 1993; Ellenberg 1996).

Fieldwork was carried out in the western part of the Central Swiss Alps at the Gemmi Pass and the Grimsel Pass (Figure 1). The Grimsel Pass is situated in the crystalline Aare massif. Rankers and Podzols have developed on its siliceous bedrock composed of granites and gneisses (Imhof 19651978; Landolt and Urbanska 1989). Long-term climate data are available from the meteorological station at Grimsel Hospiz (1980 m a.s.l.) roughly $1 \mathrm{~km}$ north of Grimsel Pass. The mean annual temperature at Grimsel Hospiz was $1.61{ }^{\circ} \mathrm{C}$ during the time period 1964-2004 (this and all subsequent values are derived from the on-line database of MeteoSwiss, Swiss National Meteorological Service). The mean annual precipitation total is $2130 \mathrm{~mm}$ of which $62 \%$ falls as snow. The snow cover is thicker than $10 \mathrm{~cm}$ during 226 days of the year and only 124 days were snow free on average. Maximum winter snow cover ranged between $1.9 \mathrm{~m} \mathrm{(1964)}$ and $6.9 \mathrm{~m} \mathrm{(1970).}$

The substrata of the Gemmi area consist of mesozoic sedimentary rocks generally rich in carbonates. Rendzinas and Alpine Brown Earths have developed on the calcareous bedrock of this area (Imhof 1965-1978; Landolt and Urbanska 1989). The climate conditions at Grimsel Hospiz are also representative for the Gemmi area (Imhof 1965-1978).

\section{Methods}

\section{Species richness}

In each plant community, the number of vascular plant species was recorded on 10 randomly selected plots $\left(1 \mathrm{~m}^{2}\right)$ at the end of July 2002. Plots were selected at distances sufficiently spaced out within the visually homogenous surface of the community to minimise spatial autocorrelation.
The mean numbers of species per community were used for the subsequent analyses.

From late July through early August 2003 above-ground standing crop was harvested by clipping the vegetation at $1 \mathrm{~cm}$ above soil surface in three randomly selected plots $\left(0.25 \mathrm{~m}^{2}\right)$ per community. Herbaceous material was dried at $70{ }^{\circ} \mathrm{C}$ for $48 \mathrm{~h}$, while woody material required drying times up to $120 \mathrm{~h}$ to reach a constant mass.

Air temperature, relative air humidity, global radiation, and wind speed were measured in each plant community during the growing seasons of 2002 and 2003. Each climate station consisted of an anemometer (type f.555.1.18, Schiltknecht, Gossau, Switzerland, installed $100 \mathrm{~cm}$ above ground), an air temperature and relative air humidity sensor (TRH 100, Pace Scientific Inc., Mooresville, N.C., USA, installed $15 \mathrm{~cm}$ above ground), a data logger (XR 440, Pace Scientific Inc., Mooresville, N.C., USA), and an amorphous solar cell (constructed at the Institute of Geography of the University of Berne, Switzerland, installed $40 \mathrm{~cm}$ above ground). Solar cells for measuring global radiation were produced and calibrated by Fischer (2002) using a pyranometer under natural irradiation conditions. The sensors were attached to a $1.3 \mathrm{~m}$ aluminium mast, with the part of the mast above the solar cells painted black to avoid reflection. Solar cells were mounted in a level position on the south side of the mast. Daily mean UV-B radiation was calculated from the measured daily mean global radiation data at the Gemmi Pass and Grimsel Pass via a linear empirical model (Vonlanthen et al. 2004). Relative air humidity measurements were converted to vapour pressure deficit (VPD: the difference between the amount of moisture in the air and how much moisture the air can hold when it is saturated) following Warnecke (1997).

Data were recorded in CEST (Central European Summer Time $=$ UTC [Universal Time Coordinated] $+2 \mathrm{~h}$ ) at 10-min intervals. These values then served as a basis from which to calculate the daily means. Missing daily mean values were interpolated using linear regressions $(2.2 \%$ of the data had to be interpolated). Microclimate stations were intercalibrated in April 2002 (i.e. prior to the first field season), in April 2003, and in October 2003 (i.e. following the second field season). Days with a minimum temperature below $0{ }^{\circ} \mathrm{C}$ (measured $15 \mathrm{~cm}$ above ground) during the growing season were defined as days with frost. Analyses 


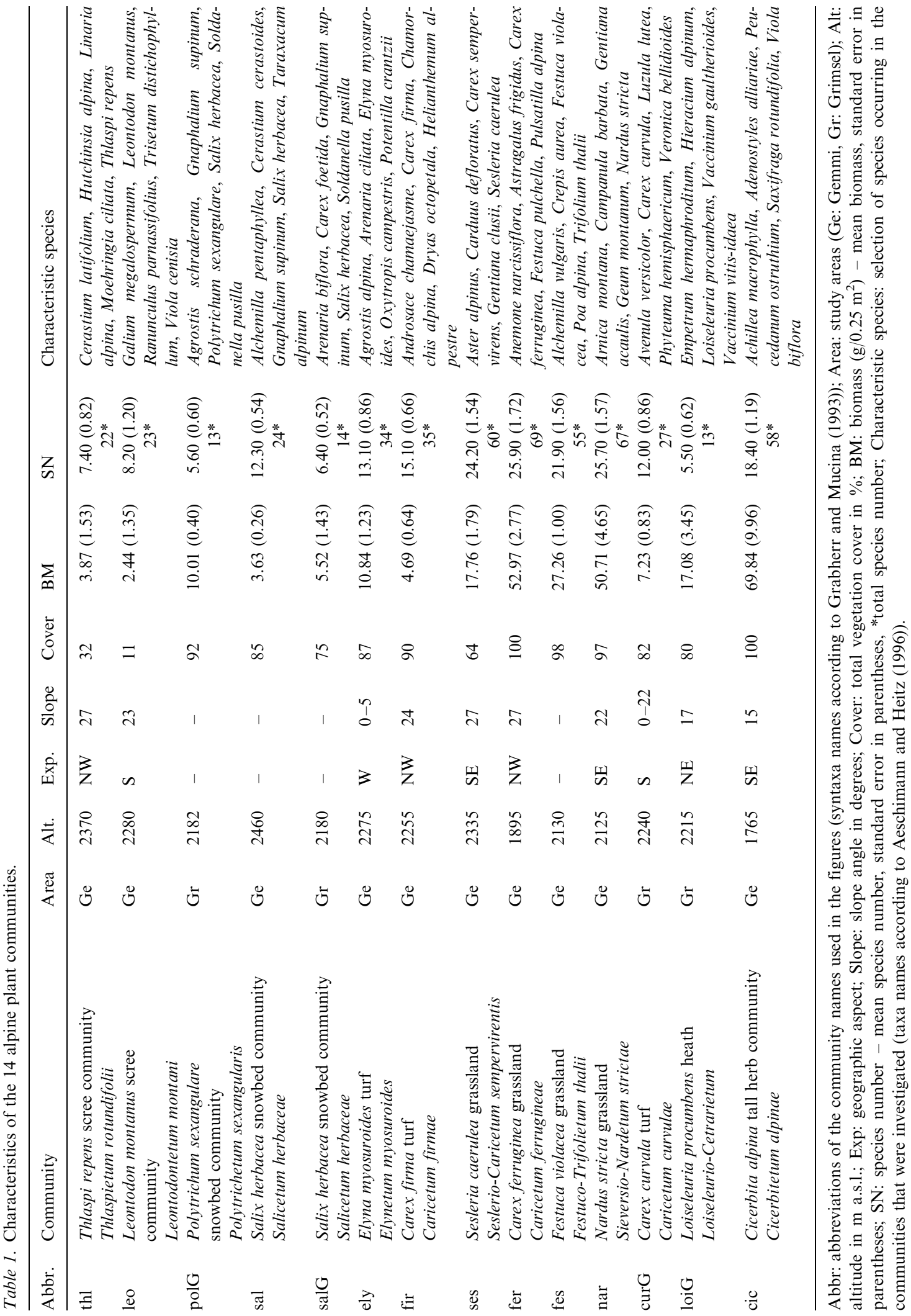




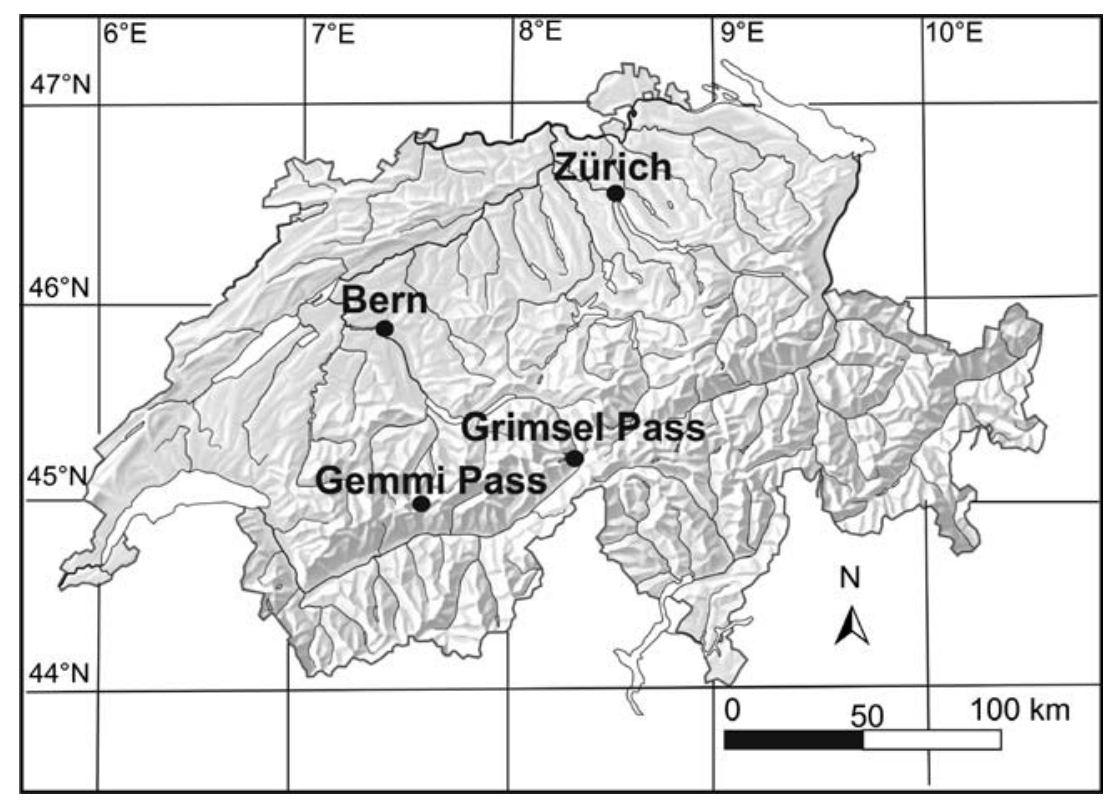

Figure 1. Location of the study sites: Gemmi Pass (calcareous bedrock), Grimsel Pass (siliceous bedrock). K606-01 (c) 2004 swisstopo.

are based on daily means, daily maximum and/or minimum values of the period during which all climate stations were functional (2002/7/12-2002/ 9/19 and 2003/7/13-2003/9/6).

Length of growing season was obtained for each community by determining the dates of snowmelt in spring, and of formation of a lasting snow cover in autumn in 2002 and 2003. Plant communities were considered snow-free as soon as all snow had disappeared from $80 \%$ of the defined surface. Analyses are based on 2-year mean values.

According to Körner (1994), periodic water shortage in the top $5 \mathrm{~cm}$ of the soil may induce water stress in plant communities above timberline. Therefore, soil suction was measured during periods of low precipitation using a Quick-Draw Tensiometer (Soil Moisture Equipment Corp., Model 2900F1, Santa Barbara, CA, USA) at a depth of $4 \mathrm{~cm}$. Soil suction was measured once in July and once in August, both in 2002 and in 2003 (altogether 4 measurement campaigns). Each time, 3 randomly placed measurements were made within 1 day in every plant community. The tensiometer was calibrated prior to each measurement. Analyses are based on mean values.

At the end of July 2003, 5 soil samples were randomly collected from the upper $5 \mathrm{~cm}$ of mineral soil in each plant community. The samples were pooled into one composite sample per com- munity. All soil samples for $\mathrm{N}_{\text {tot }}, \mathrm{NH}_{4}$, and $\mathrm{NO}_{3}$ concentration measurements were placed in an icebox $\left(-20^{\circ} \mathrm{C}\right)$ for up to $3 \mathrm{~h}$ after sampling. Concentrations of soil nutrients, including $\mathrm{N}_{\text {tot }}$, $\mathrm{NH}_{4}, \mathrm{NO}_{3}, \mathrm{P}, \mathrm{Mg}, \mathrm{Ca}$, and $\mathrm{K}$, as well as $\mathrm{pH}$, were analysed by Schweizer Samen AG (Thun, Switzerland) using standard methods described in FAL (1996). Concentrations of water soluble $\mathrm{K}, \mathrm{Mg}$, and $\mathrm{Ca}$ were determined by atomic absorption, $\mathrm{N}_{\text {tot }}$ by Kjeldahl distillation, and water soluble $\mathrm{NH}_{4}, \mathrm{NO}_{3}$, and $\mathrm{P}$ by photometry. The amount of $\mathrm{N}_{\text {org }}$ was calculated as $\mathrm{N}_{\text {tot }}$ minus $\mathrm{NH}_{4}$ minus $\mathrm{NO}_{3}$. Soil $\mathrm{pH}$ was measured by shaking $20 \mathrm{~g}$ of sieved soil with de-ionised water and measuring $\mathrm{pH}$ with a glass electrode in the solution extracted after $18 \mathrm{~h}$.

During or after periods of heavy rainfall, the proportion of waterlogged surface in each community was estimated visually (in \%) in the defined surface.

Frost upheaval was measured with a custombuilt apparatus (Vonlanthen et al. 2004) described briefly here. In August 2002, a 1.4-m steel rod was inserted $1 \mathrm{~m}$ into the ground in each plant community. Two pipe clips were fixed onto the protruding part $(40 \mathrm{~cm})$ of the steel rod. The pipe clips held a transparent tube (length of $28 \mathrm{~cm}$, diameter $2 \mathrm{~cm}$ ) in a vertical position. A grey plastic tube (length of $22 \mathrm{~cm}$, diameter $1.5 \mathrm{~cm}$ ) went through 
the transparent tube vertically, remaining free to move up and down as the soil moved. A $3 \mathrm{~cm}$ long piece of foam rubber was placed inside the transparent tube on top of the grey tube. The foam rubber was able to move upwards, but not downwards with the grey tube. Changes in the position of the foam rubber piece were measured in August 2003. To protect the apparatus against freezing it was covered by a $41-\mathrm{cm}$ high plastic tube. This apparatus measures only the maximum extent of frost upheaval.

To measure lateral soil movement, stones were labelled and aluminium bands buried vertically to a depth of $40 \mathrm{~cm}$ in every plant community in July 2002. The position of the stones and the aluminium bands were measured in August 2002 and August 2003 using a Real-Time-GPS (Leica GPS500, Heerbrugg, Switzerland, absolute precision $1.5 \mathrm{~cm}$ ). Based on these data, changes in the position of the aluminium bands and the labelled stones were calculated. In summer 2003, the vertically buried aluminium bands were dug out to detect maximum soil movement at a depth of $0-40 \mathrm{~cm}$.

The occurrence of avalanches in each community was estimated based on personal observations as well as on interviews with 10 persons familiar with the region. Avalanche frequency was quantified using a four-step scale from 0 (no avalanches) to 3 (regular occurrence of avalanches). Denudation was considered synonymous to uniform and extensive erosion of soil by water, snow, and wind. It was visually estimated and quantified using a five-step scale from 0 (more accumulation than denudation) to 4 (extremely high level of denudation).

In three permanently marked quadrats $\left(0.25 \mathrm{~m}^{2}\right)$ per community, wind damage (proportional surface area of the $0.25 \mathrm{~m}^{2}$ plot showing evidence of damage estimated to the nearest $5 \%$ ) and herbivory (proportion of the $0.25 \mathrm{~m}^{2}$ plot showing evidence of damage, estimated to the nearest $5 \%$ ) were determined every 2 weeks during the growing season. Winter dieback (proportion open ground after snowmelt) was estimated to the nearest $5 \%$ in spring in the same quadrats.

\section{Data analysis}

The relationships between species richness and stress and/or disturbance factors were explored using regression analyses. In a first step, univariate regressions were used to discover the environmental factors that produced the highest coefficients of determination $\left(r^{2}\right)$. Published reports (e.g. Engle et al. 2000) on regression analyses between species richness and stress and/or disturbance regimes usually use linear relationships, typically not exceeding second degree polynomials $\left(a+b x-c x^{2}\right)$. Residuals were tested for normal distribution (Lilliefors Test) and for homoscedasticity. For non-metric data such as denudation and avalanches a variance analysis was used to determine the relationship between environmental factors and species richness. As $\mathrm{NO}_{3}$ concentration, waterlogging, soil movement (both approaches), wind damage, and herbivory were only detectable in a few plant communities (Vonlanthen et al. 2004), these factors were not included in regression analysis.

In a second step, multivariate stepwise regressions were used to discover the models that produced the highest coefficients of determination $\left(r^{2}\right)$. Due to small sample size and in order to minimize the effect of linear dependence among variables, only one of any highly intercorrelated factors (Spearman's $r, p \leq 0.05$ ) was used in the same model. To reduce the chance of Type I error because of multiple testing, probability values were adjusted using sequential Bonferroni's procedure (Holm 1979; Legendre and Legendre 1998).

Due to the facts that the data set contained (i) non-metric data (avalanches, denudation), (ii) the number of environmental variables was larger than the number of sample sites, and (iii) some of the variables influencing every community under study were not normally distributed even after transformations $\left(\mathrm{Mg}\right.$, global radiation, $\mathrm{NH}_{4}$ concentration), we did not calculate a principal component analysis (PCA) with all the data to reduce the number of explaining variables (Legendre and Legendre 1998).

\section{Results and discussion}

The most species-poor community is the Loiseleuria heath (Table 1) with only 5.5 species $/ \mathrm{m}^{2}$ $\left(\mathrm{SN}_{\text {mean }}\right)$ and a total of 13 species. The most species rich communities are the Carex ferruginea grassland (25.9 species $/ \mathrm{m}^{2} \mathrm{SN}_{\text {mean }}$ ) and the Nardus grassland (25.7 species $\left./ \mathrm{m}^{2} \mathrm{SN}_{\text {mean }}\right)$ with a total number of up to 69 species (Table 1). 
Table 2. Simple regression analyses between species number and environmental factors.

\begin{tabular}{|c|c|c|c|c|c|}
\hline \multirow[t]{2}{*}{ Environmental factors } & \multirow[t]{2}{*}{$r^{2}$} & \multirow[t]{2}{*}{$p$} & \multicolumn{3}{|l|}{ Relationship } \\
\hline & & & Positive monotonic & Negative monotonic & Unimodal \\
\hline Daily max. temperature $\left({ }^{\circ} \mathrm{C}\right)$ & 0.72 & $0.0001^{\mathrm{a}, \mathrm{b}}$ & $\mathrm{x}$ & & \\
\hline Daily max. VPD $(\mathrm{hPa})$ & 0.71 & $0.0001^{\mathrm{a}, \mathrm{b}}$ & $\mathrm{x}$ & & \\
\hline Standing crop $\left(\mathrm{g} / 0.25 \mathrm{~m}^{2}\right)$ & 0.60 & $0.0066^{\mathrm{a}}$ & & & $\mathrm{x}$ \\
\hline $\mathrm{Mg}(\mathrm{mg} / \mathrm{kg})$ & 0.52 & $0.0183^{\mathrm{a}}$ & & & $\mathrm{x}$ \\
\hline $\mathrm{NH}_{4}(\mathrm{mg} / \mathrm{kg})$ & 0.49 & $0.0250^{\mathrm{a}}$ & & & $\mathrm{x}$ \\
\hline Length of growing season (days) & 0.48 & $0.0279^{\mathrm{a}}$ & & & $\mathrm{x}$ \\
\hline $\mathrm{pH}$ & 0.46 & $0.0349^{\mathrm{a}}$ & & & $\mathrm{x}$ \\
\hline Avalanches (classes) & 0.44 & $0.0393^{\mathrm{a}}$ & & & $\mathrm{x}$ \\
\hline Daily mean temperature $\left({ }^{\circ} \mathrm{C}\right)$ & 0.43 & $0.0109^{\mathrm{a}}$ & $\mathrm{x}$ & & \\
\hline Soil suction (cbar) & 0.41 & $0.0541^{\mathrm{a}}$ & & & $\mathrm{x}$ \\
\hline Daily mean wind speed (m/s) & 0.26 & $0.0627^{\mathrm{a}}$ & & $\mathrm{x}$ & \\
\hline Daily mean global radiation $\left(\mathrm{W} / \mathrm{m}^{2}\right)$ & 0.25 & 0.2000 & & & $\mathrm{x}$ \\
\hline Daily mean UV-B radiation $\left(\mathrm{W} / \mathrm{m}^{2}\right)$ & 0.25 & 0.2000 & & & $\mathrm{x}$ \\
\hline $\mathrm{N}_{\text {tot }}(\mathrm{g} / \mathrm{kg})$ & 0.23 & 0.2351 & & & $\mathrm{x}$ \\
\hline Frost upheaval (mm) & 0.23 & 0.2665 & & & $\mathrm{x}$ \\
\hline Daily max. wind speed $(\mathrm{m} / \mathrm{s})$ & 0.21 & $0.0978^{\mathrm{a}}$ & & $\mathrm{x}$ & \\
\hline Denudation (classes) & 0.16 & 0.3905 & & & $\mathrm{x}$ \\
\hline Daily mean VPD $(\mathrm{hPa})$ & 0.16 & 0.1513 & $\mathrm{x}$ & & \\
\hline $\mathrm{P}(\mathrm{mg} / \mathrm{kg})$ & 0.12 & 0.4995 & & & $\mathrm{x}$ \\
\hline $\mathrm{Ca}(\mathrm{mg} / \mathrm{kg})$ & 0.12 & 0.2314 & $\mathrm{x}$ & & \\
\hline Daily max. global radiation $\left(\mathrm{W} / \mathrm{m}^{2}\right)$ & 0.08 & 0.6205 & & & \\
\hline Daily max. UV-B radiation $\left(\mathrm{W} / \mathrm{m}^{2}\right)$ & 0.08 & 0.6205 & & & \\
\hline Daily min. temperature $\left({ }^{\circ} \mathrm{C}\right)$ & 0.00 & 0.9122 & & & \\
\hline Winter dieback $(\%)$ & 0.00 & 0.8326 & & & \\
\hline Days with frost & 0.00 & 0.9948 & & & \\
\hline $\mathrm{K}(\mathrm{mg} / \mathrm{kg})$ & 0.00 & 0.9953 & & & \\
\hline
\end{tabular}

$r^{2}$, coefficient of determination; $p$, probabilities; $a$, significant regressions (non-adjusted probabilities $p \leq 0.1$ ); $b$, significant regressions (probabilities adjusted according to Holm (1979)).

Only a few of our measured variables were significantly correlated with species richness. The maximum explained variance $\left(r^{2}\right.$ of 0.82 , $p<0.0001)$ was achieved with a linear two-factor model including daily maximum temperature $\left(\mathrm{T}_{\text {max }}\right)$ and soil $\mathrm{pH} \quad\left(\mathrm{SN}_{\text {mean }}=-82.95+2.39^{*}\right.$ $\mathrm{T}_{\text {max. }}+18.81^{*} \mathrm{pH}-1.64^{*} \mathrm{pH}^{2}$ ), where a monotonic influence of maximum temperature and a unimodal dependence on $\mathrm{pH}$ was found. Bivariate analyses (including the Holm correction for significance levels) and multiple regressions all show the same significant relationships between species richness and the environmental variables $\mathrm{T}_{\max }$ and $\mathrm{pH}$, while other measured variables had no significant explanatory power.

High values of explained variance (Table 2) were also found for single factor models with daily maximum temperature $\left(r^{2}\right.$ of $0.72, p<0.0001$, Figure 2a), daily maximum VPD $\left(r^{2}\right.$ of 0.71 , $p<0.0001)$, standing crop $\left(r^{2}\right.$ of $\left.0.60, p=0.0066\right)$,
$\mathrm{Mg}\left(r^{2}\right.$ of $\left.0.52, p=0.0183\right), \mathrm{NH}_{4}\left(r^{2}\right.$ of 0.49 , $p=0.0250)$, length of growing season $\left(r^{2}\right.$ of 0.48 , $p=0.0279), \mathrm{pH}\left(r^{2}\right.$ of $\left.0.46, p=0.0349\right)$, avalanches $\left(r^{2}\right.$ of $\left.0.44, p=0.0393\right)$, daily mean temperature $\left(r^{2}\right.$ of $0.43, p=0.0109)$, soil suction $\left(r^{2}\right.$ of 0.41 , $p=0.0541)$, and daily mean wind speed $\left(r^{2}\right.$ of 0.26 , $p=0.0627$ ). Two of these factors were related to species richness in a positive monotonic way (temperature, VPD), one in a negative monotonic way (wind speed), while the others (standing crop, $\mathrm{Mg}, \mathrm{NH}_{4}$, length of growing season, $\mathrm{pH}$, soil suction, avalanches) showed unimodal relationships.

In the following we focus first on the two-factor model, discuss then whether the two theoretical approaches ISH and IDH are potentially applicable to alpine plant communities, and identify where problems and deficiencies in these theoretical explanations cannot readily be solved with small data sets such as the one presented here. 

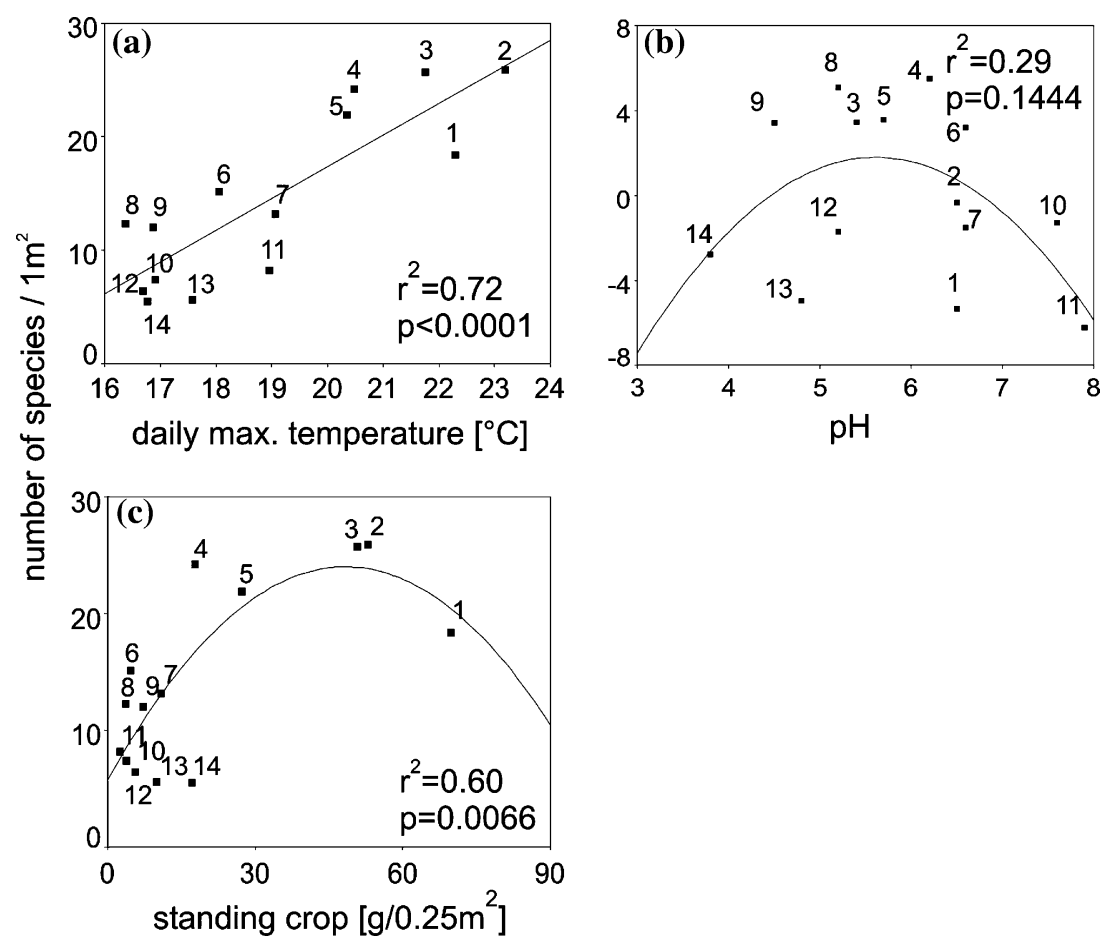

Figure 2. Simple regression analyses between species number and environmental factors. (a) daily maximum temperature; (b) partial residuals against $\mathrm{pH}$; (c) standing crop. $1=$ cic, $2=$ fer, $3=$ nar, $4=$ ses, $5=$ fes, $6=$ fir, $7=$ ely, $8=$ sal, $9=$ curG, $10=$ thl, $11=$ leo, $12=$ salG, $13=$ polG, $14=$ loiG. For abbreviations of the community names see Table 1.

\section{Two-factor model}

The model including daily maximum temperature and $\mathrm{pH}$ was highly significant and produced an $r^{2}$ of 0.82 . These two stress factors are likely to influence community species richness directly and via their effects on other environmental variables.

Temperature is likely to influence a community's species richness directly as a selective force of species occurrence, meaning that relatively cold places may not be colonised by many species of the species pool. This key position of maximum temperature would explain why one abiotic variable accounts for more than $70 \%$ of explained variance (Table 2). Experimental studies using open-top chambers to increase temperature have shown that reproductive and growth processes in arctic and alpine species are limited by temperature (e.g. Henry and Molau 1997). Apart from having direct effects on plant growth, higher temperatures most likely also lead to increased mineralisation rates (Haynes 1986). Furthermore, temperature codetermines the length of the growing season, which is one of the frequently mentioned factors control- ling the distribution of alpine plant species (e.g. Komárková 1993; Stanton et al. 1994). Temperature also influences vapour pressure deficits, soil suction, and other environmental factors that are highly correlated with species richness (Table 2).

Our study indicates that only mean and maximum temperature, but not minimum temperature, are highly correlated with species richness in a monotonic way (Figure 2a, Table 2). Minimum temperature reflects relatively short-lasting temperature conditions in the late night or early morning, when plants are still relative inactive, while maximum temperature reflects the thermal regime, sunshine, cloudiness, and weather conditions during the day. Thus, daytime temperature conditions when plants are active are more important for plant species richness than shorttime occurring daily minimum values. This finding does not exclude that episodic low temperatures over longer time periods than just a few hours around sunrise may be responsible for the local extinction of particular species (Körner 1999). The low $r^{2}$ between minimum temperature and species richness could be due to methodological problems. 
First, only the values of the period during which all climate stations were functional $(2002 / 7 / 12-$ 2002/9/19, 2003/7/13-2003/9/6) were included in the regression analysis. However, including the values of the whole vegetation period did not provide a much higher $r^{2}(0.01)$. Second, the extremely warm summer of 2003 (Vonlanthen et al. 2004) may have biased the results obtained. Though, including only the values of 2002 provided almost the same results $\left(r^{2}\right.$ of 0.01$)$.

The partial regression plot (Figure 2b) shows that the relationship between species number and $\mathrm{pH}$ is unimodal. At low soil $\mathrm{pH}$, nutrient availability decreases (Foth 1990). This may explain the low number of species in the plant communities with a low soil $\mathrm{pH}$. Species richness is also low on scree slopes, which had the highest $\mathrm{pH}$ of all plant communities under study. The high $\mathrm{pH}$ on scree slopes (situated on calcareous bedrock) is probably due to the young, weakly developed soils typical of this kind of community. At high soil $\mathrm{pH}$, micronutrient elements and the macro nutrient $\mathrm{P}$ are less available for plants (Scheffer and Schachtschabel 1998). The low species number here is most likely due not only to the high $\mathrm{pH}$ values but also to soil movement (Vonlanthen et al. 2004).

Even though at a local scale other factors may interact to reduce species richness, the importance of soil $\mathrm{pH}$ reported here is in line with numerous studies showing that $\mathrm{pH}$ is one of the factors often controlling species richness (e.g. Gough et al. 2000; Van der Welle et al. 2003). However, the more general reasons behind community differences on soils of different $\mathrm{pH}$ remain to be investigated thoroughly (Gough et al. 2000).

While regression analyses are useful in identifying possible causal factors and relationships, high coefficients of determination do not prove causality. In this study several possible mechanisms have been proposed to explain patterns of species richness. However, for some measured environmental factors (e.g. avalanches, pH) at local scale other factors may interact, thereby influencing species richness. Furthermore, the small sample size and the fact that some environmental factors were not normallly distributed limit our interpretations. Thus, these models need to be validated with a bigger sample size. Besides environmental factors, other factors such as biotic interactions and species pool effects may also co- determine species richness. On the one hand, biotic interactions such as facilitation could locally lead to a higher species number than the harshness of the environment would forecast (Callaway et al. 2002). On the other hand, communities on siliceous soils could harbour fewer species than the environment would allow since, in Central Europe, the pool of species able to colonise acid soils is smaller than that for calcareous soils (Chytrý et al. 2003; Ewald 2003).

\section{Utility of the ISH and IDH in alpine communities}

Our study reveals that some factors were related to species richness in a positive (e.g. temperature, Table 2), and negative, monotonic way (e.g. wind speed, Table 2) respectively. This suggests that the harsher the environment, the fewer species can survive in such habitats. Monotonic relationships do not conform with the ISH and IDH as these hypotheses predict a unimodal relationship. This means either that the ISH and IDH do not apply well to alpine ecosystems, or that the environmental gradients observed in our study only captured one leg of a unimodal distribution for those variables that revealed a monotonic instead of the expected unimodal behaviour.

The ISH predicts that at high levels of stress, site conditions are too harsh for many species to survive. This is confirmed by this study - e.g. species richness decreases with high soil suction or lack of water. According to the ISH, a site exposed to low levels of stress is considered favourable and one or a few species should dominate through competitive exclusion. However, in most alpine plant communities at low levels of stress, competitive exclusion may not play a major role as species numbers generally decrease due to the harsh environment and/or the interaction of other environmental factors. For example, in the snowbeds where the lowest soil suction values occurred, waterlogging leading to anaerobic conditions during rainfall periods may be partly responsible for the low species number. In addition, the short snow-free period could also be responsible for the diminution of the number of vascular plant species in the snowbeds. Thus, it seems that the number of species in the alpine zone mainly decreases at both ends of the observed environmental gradient due to the harsh environment and the interaction of 
other environmental factors, and not due to competitive exclusion. An exception may be the Cicerbita tall herb community which is situated below the timberline. In this community, the favourable growth conditions (Vonlanthen et al. submitted) and the resulting dense canopy may lead to a lower species number by competitive exclusion. This is in accordance with the study by Callaway et al. (2002), who concluded that competition generally, but not exclusively, dominates interactions among alpine plants at lower elevations where conditions are less physically stressful.

The IDH cannot easily be adapted to the disturbance factors included in our regression analysis (avalanches, denudation, frost upheaval). On the one hand, the IDH predicts that if disturbance occurs too frequently, species richness decreases because species that are intolerant to disturbance become locally extinct. This aspect is confirmed by our study - e.g. the regular occurrence of avalanches may reduce the number of species in the scree slopes. On the other hand, if disturbances are too rare the IDH predicts that richness decreases because dominant species occupy a greater share of resources and thus eliminate weak competitors. This second aspect of the IDH does not seem to apply to the alpine plant communities investigated here. At low levels of disturbance we argue that species numbers decrease most likely due to interactions among other environmental factors. For example, the small species number in the snowbeds is most likely not due to the low number of avalanches observed in these communities but to the short vegetation period (e.g. Stanton et al. 1994). Moreover, the infrequent disturbances (e.g. the low number of avalanches observed in snowbeds) may lead to low environmental heterogeneity (Palmer 1994), inhibiting the occurrence of some species.

Furthermore, this study reveals that disturbance factors do not seem to be primary in controlling species richness, since only one disturbance factor (avalanches, Table 2) had a higher coefficient of determination, and none of the disturbance factors were included in the two-factor model. This is in agreement with the study by Mackey and Currie (2000) but contradicts most other published reports (e.g. Karlson and Hurd 1993). This discrepancy may be due to several reasons. First, in our study some disturbance factors (waterlogging, lateral soil movement, wind damage, and herbivory) were only detectable in a few plant communities (Vonlanthen et al. 2004) and could therefore not be included in regression analysis. These factors seem to fine-tune species richness in specific communities, e.g. soil movement in scree slopes. Second, the scale (time and space) of measurements of the disturbance factors may have been inappropriate (White and Jentsch 2001). Third, some of the disturbance factors could not be measured as precisely as the stress factors (e.g. ordinal scale for avalanches and denudation). This may have biased the obtained results. However, the number of avalanches was the disturbance factor which showed the highest coefficient of determination of all investigated disturbance factors. Fourth, most studies emphasize the role of disturbance (albeit often only qualitatively) in particular ecosystems, such as tropical rain forests (Connell 1978), coral reefs (e.g. Karlson and Hurd 1993), herbaceous vegetation (Grime 1973), temperate forests (Horn 1975), arctic ecosystems (Fox 1981), but not in alpine ecosystems. Fifth, these studies are often restricted to analysis of a few disturbance factors and do not include the broad range of stress and disturbance factors of our study.

\section{Standing crop}

The highest amount of standing crop was measured in the Cicerbita tall herb community (Figure 2c, Table 1), while the scree slopes and the Salicetum herbacea (Gemmi Pass) had the lowest standing crop amounts (Figure 2c, Table 1). Although the highest amount of standing crop occurred in the Cicerbita tall herb community, it did not have the highest species number (Table 1). This could be due to the favourable growth conditions (Vonlanthen et al. submitted) and the resulting dense canopy which may lead to a lower species number by competitive exclusion.

Standing crop has often been used as a proxy for productivity or causal environmental factors that are difficult to measure. This study reveals that with the exception of the two-factor model $\left(r^{2}\right.$ of $0.82, p<0.0001)$, daily maximum temperature $\left(r^{2}\right.$ of $0.72, p<0.0001$, Figure $2 \mathrm{a}$ ), and daily maximum VPD $\left(r^{2}\right.$ of $0.71, p<0.0001$, Table 2$)$ more variance is explained by standing crop $\left(r^{2}\right.$ of 0.60 , $p=0.0066$, Figure 2c) than by any other investigated factor. Thus, our data seem to confirm the 
usefulness of standing crop as an easily measurable variable likely to be correlated with species richness and the productivity or the harshness of the environmental conditions of a habitat in the alpine zone. Our results contradict many studies conducted in the arctic zone (e.g. Fox 1985; Waide et al. 1999, Gough et al. 2000), which showed little correlation between species richness and standing crop. However, most of these studies were restricted to only a few community types and did not include the broad range of communities covered by this survey. Nevertheless, standing crop presumably acts only indirectly on species richness by influencing environmental conditions and competition in the community, i.e. there is no direct causality between standing crop and species richness (Kammer and Möhl 2002). Furthermore, species richness itself can also influence the standing crop of a community (e.g. Tilman et al. 1996). Testing species richness against environmental factors has therefore more explanatory power than testing species richness against standing crop (Gough et al. 1994).

\section{Conclusions}

The present study of 14 plant communities from the Swiss alpine zone revealed that $82 \%$ of the variance in vascular species richness among sites could be explained by just two abiotic factors, daily maximum temperature and soil $\mathrm{pH}$. Daily maximum temperature and $\mathrm{pH}$ affect species richness directly or via their effects on other environmental variables. Furthermore, it shows that some stress and disturbance factors were related to species richness in a monotonic way, and others in an unimodal way. Monotonic relationships suggest that the harsher the environment is, the fewer species can survive in such habitats. In cases of unimodal relationships (ISH and IDH) species richness decreases at both ends of the observed gradients due to the harsh environment and/or the interaction of other environmental factors. Competition only seemed to play a secondary role in the form of fine-tuning species richness in specific communities. An exception is the Cicerbita tall herb community where the favourable growth conditions and the resulting dense canopy seem to lead to a lower species number through competitive exclusion. Disturbance factors do not seem to be the primary factors controlling species richness with the exception of some specific communities such as scree slopes. Thus, neither the ISH nor the IDH can be considered useful conceptual models to understand the relationship between species richness and environmental stress and disturbance factors for the alpine zone. Finally, it seems that standing crop might be used as an easily measurable surrogate for causal factors determining species richness in the alpine zone, even though there is no direct causality between species richness and standing crop.

\section{Acknowledgements}

This study was supported by the "Stiftung zur Förderung der wissenschaftlichen Forschung der Universität Bern", the "Hochschulstiftung der Burgergemeinde", "the Centre of Research and Development of LLB Berne", and SEVA-Lotteriefonds (Kanton Bern). We are very grateful to all persons without whose contributions this study would not have been possible, in particular T. Reist (Bern), C. Schöb (Bern), and L. Vonlanthen (Freiburg).

\section{References}

Aeschimann D. and Heitz C. 1996. Synonymie-Index der Schweizer Flora und der angrenzenden Gebiete (SISF). Rochat \& Baumann, Genève.

Beckage B. and Stout I.J. 2000. Effects of repeated burning on species richness in a Florida pine savanna: a test of the intermediate disturbance hypothesis. J. Vege. Sci. 11: 113122.

Callaway R.M., Brooker R.W., Choler P., Kikvidze Z., Lortie C.J., Michalet R., Paolini L., Pugnaire F.I., Newingham B., Aschehoug E.T., Armas C., Kikodze D. and Cook B.J. 2002. Positive interactions among alpine plants increase with stress. Nature 417: 844-847.

Chytrý M., Tichý L. and Roleček J. 2003. Local and regional patterns of species richness in Central European vegetation types along the $\mathrm{pH} /$ calcium gradient. Folia Geobot. 38: 429 442.

Collins S.L., Glenn S.M. and Gibson D.J. 1995. Experimental analysis of intermediate disturbance and initial floristic composition: decoupling cause and effect. Ecology 76: 486492.

Connell J.H. 1978. Diversity in tropical rain forests and coral reefs. Science 199: 1302-1310.

Ellenberg H. 1996. Vegetation Mitteleuropas mit den Alpen. Ulmer, Stuttgart(5. Auflage). 
Engle D.M., Palmer M.W., Crockett J.S., Mitchell R.L. and Stevens R. 2000. Influence of late season fire on early successional vegetation of an Oklahoma prairie. J. Vege. Sci. 11: $135-144$.

Ewald J. 2003. The calcareous riddle: why are there so many calciphilous species in the Central European flora?. Folia Geobot. 38: 357-366.

FAL 1996. Schweizerische Referenzmethoden der Eidgenössischen Landwirtschaftlichen Forschungsanstalten. Band 1. Zürich Reckenholz.

Fayolle S., Cazaubon A., Comte K. and Franquet E. 1998. The intermediate disturbance hypothesis: application of this concept to the response of epilithon in a regulated Mediterranean river (Lower-Durance, southeastern France). Arch. Hydrobiol. 143: 57-77.

Fischer E. 2002. Globalstrahlungsmessung mit Solarzellen. Seminararbeit, Universität Bern (unpublished, copies can be obtained from the corresponding author).

Flöder S. and Sommer U. 1999. Diversity in planktonic communities: an experimental test of the intermediate disturbance hypothesis. Limnol. Oceanogr. 44: 1114-1119.

Foth H.D. 1990. Fundamentals in Soil Science 8. Wiley, New York.

Fox J.F. 1981. Intermediate levels of soil disturbance maximize alpine plant diversity. Nature 293: 564-565.

Fox J.F. 1985. Plant diversity in relation to plant production and disturbance by voles in Alaskan tundra communities. Arct. Alp. Res. 17(2): 199-204.

Gough L., Grace J.B. and Taylor L. 1994. The relationship between species richness and community biomass: the importance of environmental variables. Oikos 70: $271-$ 279.

Gough L., Shaver G.R., Carroll J., Royer D.L. and Laundre J.A. 2000. Vascular plant species richness in Alaskan arctic tundra: the importance of soil pH. J. Ecol. 88: 54-66.

Grabherr G. and Mucina L. (eds), 1993. Die Pflanzengesellschaften Österreichs. Teil 2. Natürliche waldfreie Vegetation, Fischer, Jena.

Grace J.B. 1999. The factors controlling species density in herbaceous plant communities: an assessment. Perspect. Plant Ecol. Evol. Syst. 2(1): 1-28.

Grime J.P. 1973. Competitive exclusion in herbaceous vegetation. Nature 242: 344-347.

Grime J.P. 1979. Plant Strategies and Vegetation Processes. Wiley, Chichester.

Grime J.P. 2001. Plant Strategies, Vegetation Processes, and Ecosystem Properties 2nd ed. Wiley, Chichester.

Haynes R.J. 1986. The decomposition process: mineralization, immobilization, humus formation, and degradation. In: Haynes R.J. (ed.), Mineral Nitrogen in the Plant-Soil system, Academic Press, Orlando, pp. 52-126.

Henry G.H.R. and Molau U. 1997. Tundra plants and climate change: the International Tundra Experiment (ITEX). Global Change Biol. 3(Suppl. 1): 1-9.

Holm S. 1979. A simple sequentially rejective multiple test procedure. Scand. J. Stat. 6: 65-70.

Horn H.S. 1975. Markovian properties of forest succession. In: Cody M.L. and Diamond J.M. (eds.), Ecology and Evolution of Communities, MA, Belknap, Cambridge, pp. 196-211.

Imhof E. (Hrsg.) 1965-1978. Atlas der Schweiz. Bundesamt für Landestopographie, Bern.
Kammer P.M. and Möhl A. 2002. Factors controlling species richness in Alpine plant communities. An assessment of the importance of stress and disturbance. Arct. Antarct. Alp. Res. 34(4): 398-407.

Karlson R.H. and Hurd L.E. 1993. Disturbance, coral reef communities, and changing ecological paradigms. Coral Reefs 12: $117-125$.

Komárková V. 1993. Vegetation type hierarchies and landform disturbance in arctic Alaska and alpine Colorado with emphasis on snowpatches. Vegetatio 106: 155-181.

Körner C. 1994. Impact of atmospheric changes on high mountain vegetation. In: Beniston M. (ed.), Mountain Environments in Changing Climates, Routledge, London, New York, pp. 155-166.

Körner C. 1999. Alpine Plant Life. Springer, Berlin.

Landolt E. and Urbanska K.M. 1989. Our Alpine Flora. Swiss Alpine Club, Chur.

Legendre P. and Legendre L. 1998. Numerical Ecology 2nd ed. Elsevier, Amsterdam.

Mackey R.L. and Currie D.J. 2000. A re-examination of the expected effects of disturbance on diversity. Oikos 88: $483-$ 493.

Mittelbach G.G., Steiner C.F., Scheiner S.M., Gross K.L., Reynolds H.L., Waide R.B., Willig M.R., Dodson S.I. and Gough L. 2001. What is the observed relationship between species richness and productivity?. Ecology 82(9): 2381-2396.

Müller P., Güsewell P. and Edwards P.J. 2003. Einfluss von Boden und Bewirtschaftung auf die Artenvielfalt der Vegetation auf Alpweiden im Glarnerland. Bot. Helvet. 113(1): 15-36.

Onipchenko V.G. and Semenova G.V. 1995. Comparative analysis of the floristic richness of alpine communities in the Caucasus and the Central Alps. J. Vege. Sci. 6: 299-304.

Palmer M.W. 1994. Variation in species richness: towards a unification of hypotheses. Folia Geobotanica et Phytotaxonomica 29: $511-530$.

Rosenzweig M.L. and Abramsky Z. 1993. How are diversity and productivity related?. In: Ricklefs R.E. and Schluter D. (eds.), Species Diversity in Ecological Communities, University of Chicago Press, Chicago, pp. 52-65.

Scheffer F. and Schachtschabel P. 1998. Lehrbuch der Bodenkunde. F. Enke, Stuttgart(14. Auflage).

Sommer U. 1995. An experimental test of the intermediate disturbance hypothesis using cultures of marine phytoplankton. Limnol. Oceanogr. 40: 1271-1277.

Stanton M.L., Rejmánek M. and Galen C. 1994. Changes in vegetation and soil fertility along a predictable snowmelt gradient in the Mosquito Range, Colorado, U.S.A. Arct. Alp. Res. 26: 363-374.

Tilman D., Wedin D. and Knops J. 1996. Productivity and sustainability influenced by biodiversity in grassland ecosystems. Nature 379: 718-720.

Van der Welle M.E.W., Vermeulen P.J., Shaver G.R. and Berendse F. 2003. Factors determining plant species richness in Alaskan arctic tundra. J. Vege. Sci. 14(5): 711-720.

Vonlanthen C., Bühler A., Veit H., Kammer P. and Eugster W. 2004. Charakterisierung ökologischer Standortfaktoren in alpinen Pflanzengemeinschaften. Naturforschende Gesellschaft Bern 61: 49-77.

Vonlanthen C.M., Kammer P.M., Eugster W., Bühler A., and Veit H. Alpine plant communities: an assessment of their 
relation to microclimatological, pedological, geomorphological, and other factors (submitted).

Waide R.B., Willig M.R., Steiner C.F., Mittelbach G., Gough L., Dodson S.I., Juday G.P. and Parmenter R. 1999. The relationship between productivity and species richness. Annu. Rev. Ecol. Syst. 30(1): 257-300.

Warnecke G. 1997. Meteorologie und Umwelt - eine Einführung. Springer, Berlin, Heidelberg(2. Auflage).
White A.S., Witham J.W., Hunter J., Malcolm L. and Kimball A.J. 1999. Relationship between plant species richness and biomass in a coastal Maine Quercus-Pinus forest. J. Vege. Sci. 10: $755-762$.

White P.S. and Jentsch A. 2001. The Search for Generality in Studies of Disturbance and Ecosystem Dynamics. Progress in Botany 62. Springer, Berlin, pp. 399-449. 